Resumen por la autora, Mary T. Harman.

Sobre el orígen del notocordio en el pollo.

Dos pollos anormales producidos en nuestro laboratorio presentaban notocordios excepcionales. Ambos fueron incubados durante tres dias. Uno de ellos fué incubado a una temperatura de $106^{\circ} \mathrm{F}$. y el otro a una temperatura de $99^{\circ}$ a $100^{\circ} \mathrm{F}$. En el primer pollo el notocordio es bifurcado en su extremo anterior, en proximamente un tercio de su longitud. En esta misma región el tubo neural está también bifurcado ventralmente. El intestino no presenta indicio alguno de bifurcación. En el segundo pollo el notocordio en el extremo posterior no solo está en contacto con el tubo neural, sino que se continúa con él. El endodermo del saco vitelino está por completo separado del notocordio. Las condiciones excepcionales descritas constituyen pruebas en favor de la teoría del orígen ectodérmico del notocordio. 


\title{
CONCERNING THE ORIGIN OF THE NOTOCHORD
} IN THE CHICK ${ }^{1}$

\author{
MARY T. HARMAN \\ Kansas State Agricultural College, Manhattan, Kansas \\ ONE PLATE (FIVE FIGURES)
}

The presence of the chorda dorsalis or notochord sometime during the life-history is one of the characteristics which distinguishes the Chordata from the other phyla of the animal kingdom. As to its origin, few other embryonic structures have received more attention from investigators, and yet there exists the greatest diversity of opinion concerning its early embryonic development. All three germ layers have been given as its origin. As early as 1881 Hatschek described the notochord as being folded off from the primitive gut. This is the view held by Hertwig ('05), McMurrich ('15), and others. Prentiss and Arey ('17) say that "the head (notochordal) process and mesoderm of higher vertebrates are not clearly of entodermal origin, but are derived from the ectoderm, any union with the entoderm being secondary." Huber ('18) also considers the notochord to be of ectodermal origin, which becomes associated with the entoderm, and then afterward separated from it. King ('03) says that in Bufo lentiginosus the anterior part of the notochord is entirely mesodermal in origin, and that in the posterior part it is mostly derived from mesoderm, but that there is added to it a layer of entoderm from the archenteron.

These differences of opinion are not entirely due to the fact that the investigators have been working with different vertebrates, for Foster and Balfour ('83) say that in the chick the notochord in most instances arises from the anterior end of the

1 Contribution from the Zoological Laboratory, Kansas State Agricultural College, no. 57. 
primitive streak and remains attached to the 'hypoblast' (entoderm), but in other cases the notochord appears to become differentiated in the already separated layer of mesoderm. Prentiss and Arey ('17) say that the notochordal plate in birds is mesodermal in origin and later becomes fused with the entoderm. However, they state that the mesodermal plate which goes to form the notochord arises from the thickened ectoderm of the primitive streak.

These great differences of the opinions of able investigators have led the writer to record some abnormal conditions in the notochord of some teratological specimens of the chick produced in our laboratory (Harman, '18; Alsop, '19). It is not the purpose of the writer to give an extended discussion of the vast amount of literature on the origin of the notochord which must of necessity include the origin of the germ layers, but rather to present the conditions as found in these specimens and discuss to some extent the possible bearing upon the theories of the origin of the notochord.

The illustrations are taken from two of the specimens referred to above. Both chicks were incubated for three days. One was incubated at a temperature of about $106^{\circ} \mathrm{F}$., and in addition to a very abnormal central nervous system has a bifurcate notochord. The double condition is in the anterior end and extends caudad to the region of the origin of the vitelline veins. Transverse sections of this specimen are represented in figures 1,2 , and 3 . The other chick was incubated at a temperature of between $99^{\circ} \mathrm{F}$. and $100^{\circ} \mathrm{F}$. The abnormal condition of the notochord is shown in figures 4 and 5 .

Figure 1 is a section through the chick about $50 \mu$ from the extreme anterior end of the notochord. The notochord, marked $n c$ in the figure, is rather small, cylindrical in shape, and instead of being in a median line ventral to the hind-brain, marked $n t$ in the drawing, it is in two parts or cylinders located a little to either side of the midventral line. The hind-brain in this region encloses two cavities, a larger dorsal cavity and a very small ventral one. The small cavity is slightly forked ventrally. The respective horns are in a direct line with the noto- 
chord of that side. The pharynx, marked $g$ in this section, has no indication of the double condition dorsally.

The notochord is double for a distance of about $1 \frac{1}{4} \mathrm{~mm}$. or through the heart region, a distance of about one-third of its entire length. Figure 3 is a drawing of a section at the point of the convergence of the two horns of the notochord. Figure 2 is a drawing of a section about midway between the sections represented in figures 1 and 3 . It will be noted that in figure 3 the notochord is large compared with the double notochord represented in the other two figures. It also has a slight indication of its double condition. The neural tube here also is somewhat double ventrally. Posterior to this region, both the notochord and neural tube are single and appear to be normal for this stage of development. Anterior to this region, the two parts of the notochord gradually diverge and the respective horns become smaller to the region represented in figure 2 . Then they come a little closer together, but remain about the same size, as is shown in figure 1. The two cavities of the central nervous system are found only in three sections, but the bifurcate condition of the ventral side of the central nervous system is very distinct in the entire region of the double notochord.

Figures 4 and 5 are drawings of sections through the posterior third of a three-day chick incubated at a temperature between $99^{\circ} \mathrm{F}$. and $100^{\circ} \mathrm{F}$. The section represented by figure 4 is about $\frac{1}{3} \mathrm{~mm}$. anterior to the other one. The neural tube in this region is not quite normal, but its abnormality is more striking a few sections anterior where they are two and three central canals as previously described (Harman, '18; Alsop, '19). As shown in figure 4 , the notochord seems to be directly continuous with the neural tube, although the two are almost separated. The entoderm, en, of the yolk sac lies close to but entirely separated from the notochord. Posteriorly, as shown in figure 5, the continuity of the notochord with the neural tube is more conspicuous. In fact, the constriction between the notochord and the neural tube is not very deep, and an examination of the cells with the high power of the microscope shows that they are of the same character in both of the structures. The entoderm of the yolk sac is in contact with the notochord, but is distinet from it.

THE ANATOMICAL RECORD, VOL. 23 , No. 7 
In the case of the first chick, two hypotheses may be considered: either the notochord became bifurcate at the time of its formation or after it was formed. If the former, the factor or factors which by their influence caused the doubling would have affected the structure from which the notochord originated and we should expect an indication, at least, of a double condition of this structure; if the latter, we must suppose the doubling. to be accompanied by a growth in its diameter, since each of the paired notochords is of nearly normal size. It is well known that increase in diameter is not normally noticeable in the chick notochord, as the chief difference between that of a one-day chick and that of a three-day chick is in its length. It is evident that increase in length could not produce bifurcation. Therefore, it is hardly probable that bifurcation occurred after the notochord was formed, and we can return to the assumption that the notochord became bifurcate at the time of its formation.

Surrounding the notochord is mesoderm, ventral to it is the gut which is entodermal in origin, and dorsal to it is the neural tube which is ectodermal in origin. If the notochord came from the surrounding mesoderm, it probably developed in situ, since there is no indication of a doubling of the mesodermal structures. The writer sees no condition in favor of this hypothesis and on the other hand no direct evidence against it. If it has arisen in situ it is unique among compact structures of embryonic devclopment which usually arise from a region of unequal proliferation of cells which finally results in a folding or in the formation of a thickened plate. Since there is no evidence of an unequal proliferation of mesodermal cells, the indirect evidence is rather against the theory of the mesodermal origin of the notochord.

If we assume that the notochord is entodermal in origin, we will have to accept that it came from the gut or from the yolk sac before the gut was formed, for these are the only structures of this region of entodermal origin. There is no indication of a doubling of the gut; therefore, from our hypothesis the notochord cannot be entodermal in origin. Then it must be ectodermal, since, as we have shown, it is hardly probable that it is either mesodermal or endodermal. Let us examine the evidence for the hypothesis of its ectodermal origin. 
If it were ectodermal in origin, it must have come from the ventral surface of the neural tube. As we have shown previously, the neural tube in the region of the double notochord is double ventrally and where it is single the neural tube is also single. Furthermore, in a normal chick the notochord lies ventral to the median line of the neural tube and the single canalis centralis is in direct line with the notochord. In this specimen the canalis centralis is forked ventrally. If the respective forks of the canalis centralis should be considered as being in the ventral portion of a complete neural tube, then the notochord of the respective sides would have a normal position with reference to the neural tube.

It would seem, then, either that some factor or factors affected the notochord and the neural tube, at the same time causing both of them to bifurcate at least partially, or that they caused the formation of two neural grooves instead of one and that the notochord arose from the ventral surface of the neural tube. This seems all the more probable since both structures are double in the same place and since they are the only structures of this region showing this condition. Therefore, the facts indicate that the notochord became forked at the time it was formed and that it came from the ectoderm.

The condition in the second chick gives added evidence that the notochord has arisen from the ventral part of the neural tube or at least from the ectoderm from which the neural tube is formed. As was given above in figure 4, the neural tube is continuous with the notochord, while in figure 5 not only are they continuous, but it is impossible to tell where neural tube stops and notochord begins. Moreover, the entoderm of the yolk sac is completely separated from the notochord. It seems, then, that the notochord is ectodermal in origin.

To summarize, then, the bifurcate condition of the notochord and a similar condition in the ventral portion of the neural tube in the case of the first described, together with the absence of evidence of a double condition in any other structure in this region, is evidence in favor of the theory that the notochord in the chick is ectodermal in origin. In the case of the second chick, the continuity of the cells of the neural tube with those of the 
notochord as well as the complete separation of the entoderm of the yolk sac from the notochord is added evidence for the theory of the ectodermal origin of the notochord.

\section{LITERATURE CITED}

Alsop, Florence MAY 1919 The effect of abnormal temperatures upon the developing nervous system in the chick embryo. Anat. Rec., vol. 15.

Foster, M., and Balfotr, Francis M. 1883 The elements of embryology. Macmillan \& Co.

Harman, Mary T. 1918 Abnormalities in the chick embryo. Science, N. S., vol. 48 , no. 1245 .

Hatschek, B. 1881 Studien über die Entwicklung des Amphioxus. Arbeiten a. d. zool. Inst. Wien. und Triest, Bd. 4.

Hertwig, Oscar 1905 Embryology of man and mammals, translated by Edward L. Mark. Swan Sonnenschein \& Co., New York.

Hober, G. Carl 1918 On the anlage and morphogenesis of the chorda dorsalis in mammalia, in particular in the guinea-pig (Cavia cobaya). Anat. Rec., vol. 14.

King, Helen Dean 1903 The formation of the notochord in Amphibia. Biol. Bull., vol. 4.

McMurrich, J. Playfair 1915 The development of the human body. P. Blakiston's Son \& Co., Philadelphia.

Prentiss, Charles William, and Arey, Leslie Brainerd 1917 A laboratory manual and text book of embryology. W. B. Saunders Co., Philadelphia.

\section{PLATE 1}

\section{EXPLANATION OF FIGURES}

All figures were enlarged about 135 diameters and then reduced one-half.

Figures 1, 2, and 3 are sections through a three-day chick incubated at $106^{\circ} \mathrm{F}$. Figures 4 and 5 are sections through a three-day chick incubated at $99^{\circ} \mathrm{F}$. to $100^{\circ} \mathrm{F}$.

1 Section through the anterior portion of the notochord. nc, notochord; $g$, gut; $n t$, neural tube.

2 Section through the middle of the heart. $n c$, notochord; $g$, gut; $n t$, neural tube.

3 Section through the orgin of the vitelline veins. $n c$, notochord; $g$, gut; $n t$, neural tube.

4 Section through the chick about one-third of its length from the posterior end. $n t$, neural tube; nc, notochord, en, entoderm of yolk sac.

5 Section through the chick about $\frac{1}{3} \mathrm{~mm}$. poterior to the section represented in figure 4. 

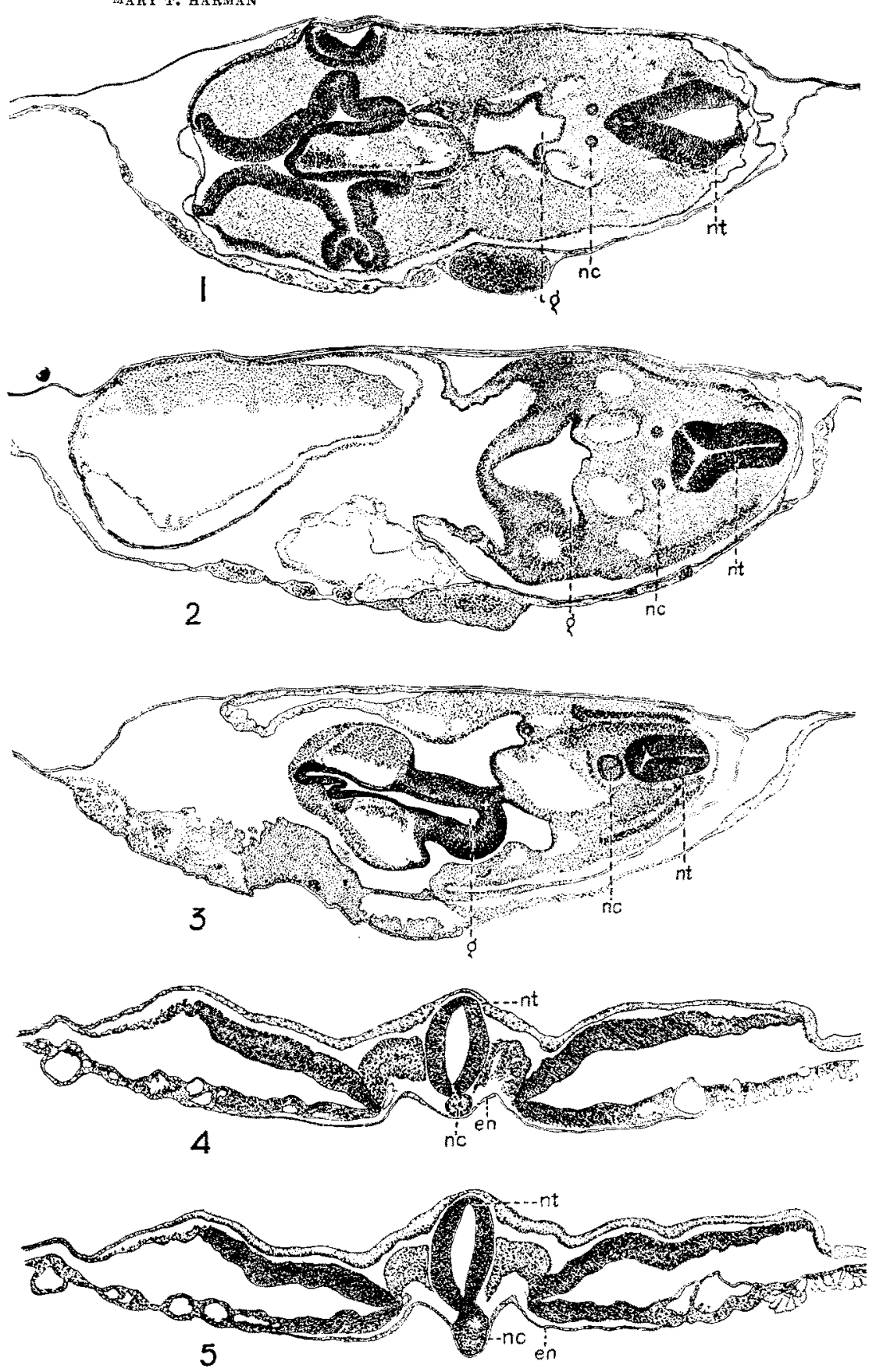